
Shuster

\title{
Effect of Cd and SPD on structure, physical, mechanical, and operational properties of alloy of Cu-Cr-Zr
}

https://doi.org/10.1515/rams-2020-0045

Received Apr 30, 2020; accepted Aug 17, 2020

\begin{abstract}
An increase in the service life of electrical products from copper and its alloys is directly related to an increase in the wear resistance of materials. Structural refinement and alloying with cadmium are known to have a positive effect on the strength characteristics and wear resistance of copper, which makes it possible, with a $\mathrm{Cd}$ content of $1 \%$ by weight, to increase the wear resistance of copper several times, but cadmium is considered an environmentally unsafe element. In this regard, the paper presents the results of studies of a widely used $\mathrm{Cu}-\mathrm{Cr}-\mathrm{Zr}$ alloy system in the ultrafine-grained (UFG) state, microalloyed with cadmium ( $0.2 \%$, weight), in order to improve physical, mechanical, and operational properties, as well as environmental safety. Severe plastic deformation, providing structure refinement to $\sim 150 \mathrm{~nm}$, and microalloying with cadmium of a $\mathrm{Cu}$-Cr-Zr system alloy, after a complete processing cycle, provides a tensile strength of $570 \pm 10 \mathrm{MPa}$ and $67 \%$ electrical conductivity. At the same time, the abrasion resistance increases by 12 and 35\% relative to the industrial systems $\mathrm{Cu}-\mathrm{Cd}$ and $\mathrm{Cu}-\mathrm{Cr}-\mathrm{Zr}$, respectively. The obtained characteristics are very promising for improving the operational properties of continuous welding tips, collector plates, and contact wires operating under conditions of intense wear.
\end{abstract}

Keywords: low alloy copper alloys, ECAP, tribological and mechanical properties

\footnotetext{
${ }^{\star}$ Corresponding Author: Denis A. Aksenov: Ufa State Aviation Technical University, 12 K. Marx str., 450077, Ufa, Russia; Institute of Molecule and Crystal Physics UFRC RAS, 151 Prospekt Oktyabrya, 450075, Ufa, Russia; Email: aksyonovda@mail.ru Georgiy I. Raab, Vladimir I. Semenov, Lev Sh. Shuster: Ufa State Aviation Technical University, 12 K. Marx str., 450077, Ufa, Russia Rashid N. Asfandiyarov: Ufa State Aviation Technical University, 12 K. Marx str., 450077, Ufa, Russia; Institute of Molecule and Crystal Physics UFRC RAS, 151 Prospekt Oktyabrya, 450075, Ufa, Russia
}

\section{Introduction}

Increasing the service life of electrical products made of copper and its alloys, such as contact wires, contact tips for continuous welding, and commutator segments of DC machines (engines, generators), is related to the wear resistance of used materials. For example, increasing the overhaul life by replacing commutator copper with silver additives with cadmium bronze alloy $\mathrm{Cu}-1 \% \mathrm{Cd}$ provides 2-2.5 times enhancements in wear resistance. Thus, the mileage for electric freight locomotives increases to 600 thousand $\mathrm{km}$ and up to 1 million $\mathrm{km}$ for passenger locomotives without overhaul of commutators. Therefore, monetary and temporary losses associated with replacing failed units are noticeably reduced. Contact tips for automatic and semi-automatic welding machines operating in conditions of intense sliding contact are also of interest. This type of welding is widespread in modern mass production of goods, and increasing the contact endurance of tips is very important. Wear is influenced not only by the chemical composition but also by the strength properties of the product material. Therefore, in order to increase the surface strength, collector plates are subjected to knurling or shock-acoustic treatment. Recently, severe plastic deformation (SPD) has been used as a hardening method, which makes it possible to obtain ultrafine-grained (UFG) structures in materials with a grain sizes of $200-400 \mathrm{~nm}$ and, accordingly, strength (hardness) characteristics increase several times compared to the initial state. For example, the formation of an UFG structure in copper M1 leads to an increase in hardness up to $1400 \mathrm{MPa}$ and a decrease in the friction coefficient by 0.07 , in chrome bronze by 0.05 [1-3]. In works [4, 5], using the example of nanostructured bronze of the $\mathrm{Cu}-\mathrm{Cr}-\mathrm{Zr}$ system, nanostructuring of the material led to a more significant decrease in the friction coefficient than the subsequent precipitation hardening of the material. At the same time, at the initial stages of deformation by SPD methods, it was possible to reduce the wear resistance of the material, which is associated

OOpen Access. (c) 2020 D. A. Aksenov et al., published by De Gruyter. (CC) BY 4.0 License 
with the brittle fracture mechanism of the material during wear [6]. The works considered above concern analysis of the grain structure refinement effect and precipitation hardening on strength, electrical conductivity, and wear resistance. At the same time, the question of integral solid solution hardening and its effect on the properties in dispersion hardening materials is not often raised. This area includes studies of the Cu-Cr-Ag system alloy [7, 8]. However, Ag is inferior to $\mathrm{Cd}$ in terms of wear resistance of the copper matrix. This paper presents a comparative analysis of the strength characteristics, electrical conductivity, and wear resistance of industrial alloys of the $\mathrm{Cu}-\mathrm{Cr}-\mathrm{Zr}$ and $\mathrm{Cu}$ $\mathrm{Cd}$ systems with an alloy of the $\mathrm{Cu}-\mathrm{Cr}-\mathrm{Cd}-\mathrm{Zr}$ system in the UFG state, obtained by the SPD -equal-channel angular pressing (ECAP) method.

\section{Experimental procedure}

Casting of the $\mathrm{Cu}-\mathrm{Cr}-\mathrm{Cd}-\mathrm{Zr}$ system alloy (Table 1) was fulfilled by heating in a crucible with coal to $1150^{\circ} \mathrm{C}$ and subsequent chill casting. The produced cast billet of $\varnothing 32 \mathrm{~mm}$ was turned to a diameter of $\varnothing 28 \mathrm{~mm}$ and rolled to $\varnothing 12 \mathrm{~mm}$. After that, the workpiece was heated in an oven at $1050^{\circ} \mathrm{C}$ for $1 \mathrm{~h}$ and, then, quenched in water.

Table 1: Chemical analysis of the cast (\% wt.)

\begin{tabular}{lllll}
\hline Elements & $\mathrm{Cu}$ & $\mathrm{Cr}$ & $\mathrm{Cd}$ & $\mathrm{Zr}$ \\
\hline$\%$ wt. & 99.23 & 0.55 & 0.20 & 0.02 \\
\hline
\end{tabular}

Deformation by ECAP was carried out at room temperature. The angle of the channels' intersection was $90^{\circ}$. The number of deformation cycles was eight. The processing route was Bc. After deformation, samples of $\varnothing 10 \mathrm{~mm}$ and $60 \mathrm{~mm}$ long were obtained. Post-deformation heat treatment (aging) was carried out at $400^{\circ} \mathrm{C}$ for $1 \mathrm{~h}$ in salts.

The structure was characterized by transmission electron microscopy (TEM) using a JEM 2100. Chemical analysis of the material before and after deformation was carried out through energy-dispersion analysis using a JEOL JSM6490LV scanning electron microscope (SEM). Tribological tests were carried out according to the scheme of reciprocating motion on a Nanovea TRB tribometer. Alloys of $\mathrm{Cu}-\mathrm{Cr}-\mathrm{Cd}-\mathrm{Zr}$, $\mathrm{Cu}-\mathrm{Cr}-\mathrm{Zr}$, and $\mathrm{Cu}-\mathrm{Cd}$ systems, with a surface roughness of no more than $0.05 \mu \mathrm{m}$ and a ball of steel ShKh15 with a diameter of $6 \mathrm{~mm}$, were used as "friction pairs.” The load was $1 \mathrm{~N}$, and the ball speed was 3600 $\mathrm{mm} / \mathrm{min}$ with a path length of $1000 \mathrm{~m}$. The indenter's travel to change direction was $20 \mathrm{~mm}$. The analysis of the track width after wear tests was carried out on light microscope Olympus GX51.

To assess the shear strength of adhesive bonds and the molecular component of the coefficient of friction, test samples, in the form of parallelepipeds, with crosssections of $9.5 \times 9.5 \mathrm{~mm}$ and thicknesses of $5 \mathrm{~mm}$ were used. A spherical indenter with a sphere radius of $2.5 \mathrm{~mm}$ was made of tool steel R6M5. Tests to determine the shear strength of adhesive bonds were carried out on a one-ball adhesiometer according to the scheme shown in Figure 1. The tests were carried out at two temperatures (20 and $150^{\circ} \mathrm{C}$ ) without lubricants.

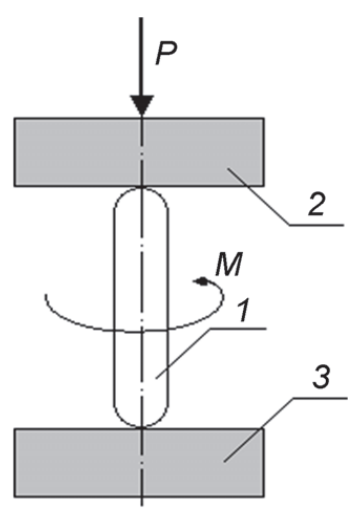

Figure 1: Test scheme for determining the strength of adhesive bonds on the slice and the molecular component of the coefficient of friction: 1-spherical indenter; 2 \& 3-test samples.

The method for determining the shear strength of adhesive bonds is based on a physical model, which, at first approximation, reflects the real friction conditions at a local contact [9]. According to this model, spherical indenter 1 in contact with two plane-parallel samples, 2 and 3, with a fixed axial load P rotates around its own axis under torque $M$. The torque $M$ value, ensuring the indenter rotation, depends mainly on the shear strength of adhesive bonds, $\tau_{n}$, and the contact area. Thus, the shear strength of adhesive bonds $\tau_{n}(\mathrm{MPa})$ was determined from the ratio:

$$
\tau_{n}=0,75 \cdot \frac{M}{\pi \cdot\left(\frac{d_{1,2}}{2}\right)^{3}},
$$

where $d_{1,2}$ is the indent diameters on the test samples $(\mathrm{mm})$, and $\mathrm{M}$ is the torque upon indenter rotation $\left(\mathrm{N}^{\star} \mathrm{mm}\right)$. The adhesive (molecular) component of the friction coefficient was determined as:

$$
f_{M}=\frac{\tau_{n}}{p_{r}}
$$




$$
p_{r}=\frac{P}{\pi \cdot\left(\frac{d_{1,2}}{2}\right)^{2}}
$$

where $p_{r}$ is the normal pressure (MPa), and $P$ is the compression force $(\mathrm{N})$.

\section{Results and discussion}

\subsection{Structural studies}

The cast alloy of the Cu-Cr-Zr-Cd system had a coarsegrained structure with an average grain size of $90 \pm 4 \mu \mathrm{m}$. A large number of triangular, rhomboid, hexagonal, and elongated particles were observed along the boundaries and in grain interiors (Table 2).

Homogenizing annealing at $1050^{\circ} \mathrm{C}$ for $1 \mathrm{~h}$, followed by quenching in water, led to the formation of a coarsegrained structure with an average grain size of $140 \pm 5 \mu \mathrm{m}$. Quenching sustains the state of the supersaturated solid solution of alloying elements in the material matrix. On one hand, for an alloy of the Cu-Cr-Cd-Zr system, this makes it possible to increase the degree of matrix hardening due to the content of cadmium in it. On the other hand, the state of a solid solution in heat-strengthened copper al-
Table 2: Chemical analysis of particles

\begin{tabular}{lllll}
\hline \multirow{2}{*}{ Element } & \multicolumn{4}{l}{ Average content, \% wt. } \\
\cline { 2 - 5 } & Triangle & Hexagonal & $\begin{array}{l}\text { Rhomb- } \\
\text { shaped }\end{array}$ & Elongated \\
\hline $\mathrm{Cu}$ & 99.27 & 99.07 & 99.45 & 57.3 \\
$\mathrm{Cr}$ & 0.23 & 0.32 & 0.34 & 42.55 \\
$\mathrm{Cd}$ & 0.5 & 0.61 & 0.21 & 0.15 \\
\hline
\end{tabular}

loys provides the implementation of the mechanism hardening both at the stage of deformation and at the stage of aging [10-13].

After quenching, large rhomb-shaped and hexagonal particles disappear. Copper-chromium triangular particles remain, located in grain bodies and elongated particles in grain bodies and boundaries (Figure 2). The average results of point chemical analysis of particles are presented in Table 3. The average particle transverse size was $1000 \pm 80 \mathrm{~nm}$. The chemical analysis indicated the presence of cadmium in the copper matrix, on the order of $0.2 \%$ wt.

When studying the structure at the mesoscale level after deformation by eight ECAP cycles, the presence of elongated and spherical-shaped clusters of large particles (Figure 3a) with average transverse sizes of $520 \pm 30 \mathrm{~nm}$
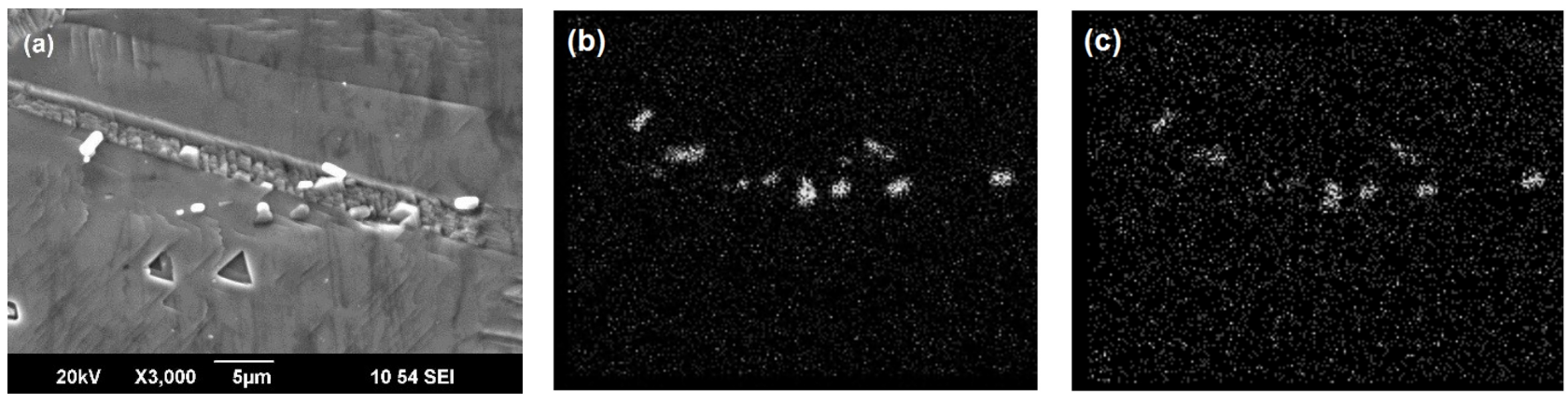

Figure 2: Alloy of the $\mathrm{Cu}-\mathrm{Cr}-\mathrm{Cd}$-Zr system after homogenization annealing $\left(1050^{\circ} \mathrm{C}\right)$ with quenching: a-structure (SEM), b-Cr distribution pattern; $c-Z r$ distribution pattern.
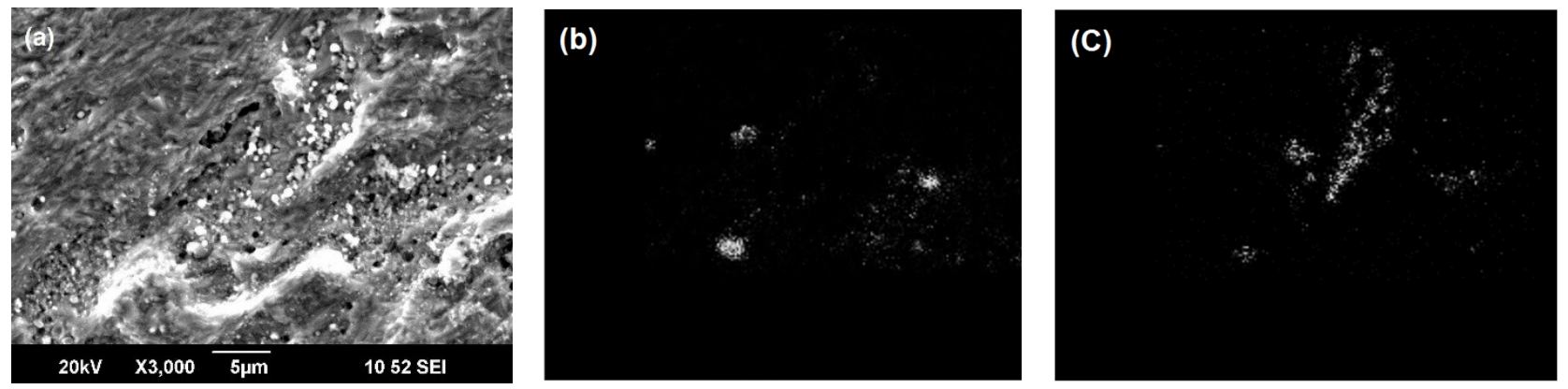

Figure 3: Alloy Cu-0.55Cr-0.2Cd-0.02Zr after eight ECAP cycles: a-structure (SEM); b-Cr distribution pattern; c-Zr distribution pattern. 
Table 3: Chemical analysis of particles

\begin{tabular}{llllll}
\hline \multirow{2}{*}{ Element } & \multicolumn{5}{l}{ Average content, \% wt. } \\
\cline { 2 - 6 } & \multicolumn{1050}{l}{$\mathrm{C}$ 1h } & \multicolumn{5}{l}{ Eight ECAP cycles } & Eight ECAP cycles+HT \\
\cline { 2 - 6 } & Triangle & Elongated & Spherical & Elongated & Spherical and elongated \\
\hline $\mathrm{Cu}$ & 99.28 & 40.06 & 50.17 & 52.42 & 26.15 \\
$\mathrm{Cr}$ & 0.54 & 41.29 & 1.85 & 32.21 & 52.91 \\
$\mathrm{Cd}$ & 0.18 & - & - & - & - \\
$\mathrm{Zr}$ & - & 18.65 & 47.98 & 15.32 & 20.94 \\
\hline
\end{tabular}

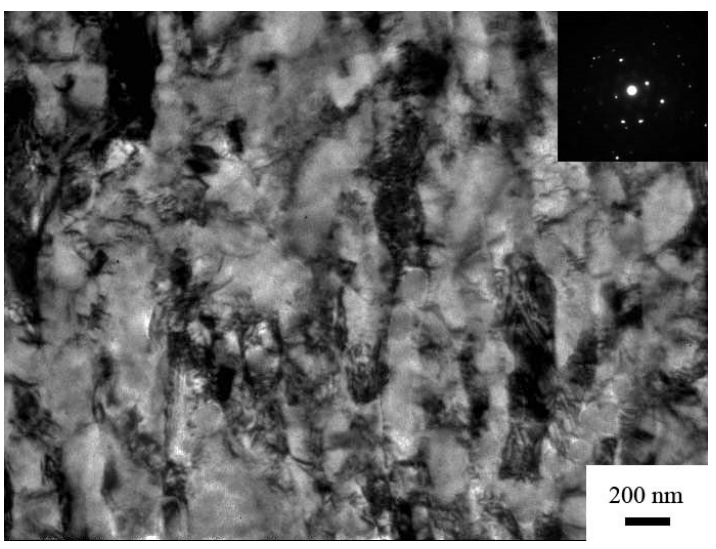

Figure 4: Structure (TEM) of the Cu-0.55Cr-0.2Cd-0.02Zr alloy after eight ECAP cycles.

were noted. The formation of spherical particles saturated with zirconium is possibly associated with the processes of mechanical fragmentation - fracture of elongated particles during ECAP and dissolution of chromium in a copper matrix due to an increase in the surface energy of particles [13]. According to the TEM results, ultrafine particles (less than $100 \mathrm{~nm}$ in size) were not observed in grain bodies. ECAP led to significant refinement of the structure and elongation of structural components (Figure 4). The average transverse fragment size was $155 \pm 7 \mathrm{~nm}$.

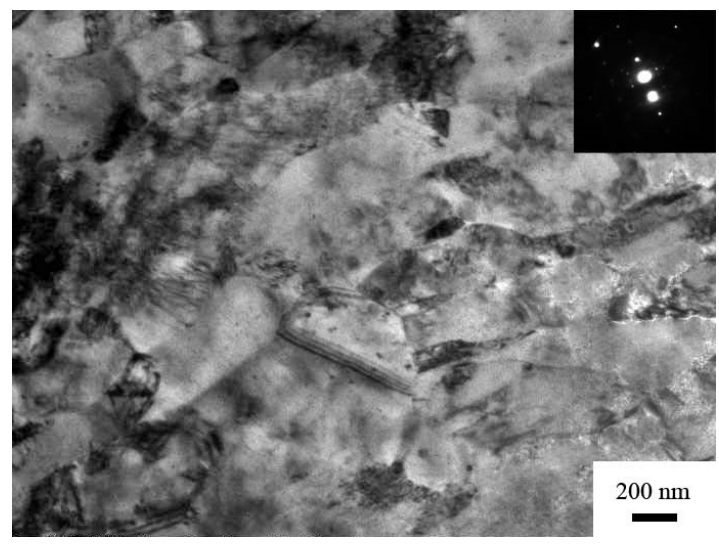

Figure 6: Structure (TEM) of the $\mathrm{Cu}-0.55 \mathrm{Cr}-0.2 \mathrm{Cd}-0.02 \mathrm{Zr}$ alloy after eight ECAP cycles + TO at $400^{\circ} \mathrm{C}$ for $1 \mathrm{~h}$.

Aging led to the disappearance of clusters of large particles in the material matrix. However, the average particle size became slightly larger, $780 \pm 30 \mathrm{~nm}$, which may be due to particle coalescence. Chemical analysis of the particles (Table 3) indicates conservation of copperchromium-zirconium particles of spherical and elongated shapes (Figure 5). Studies on the microstructure of the samples showed an increase in the average transverse size of the fragments to $215 \pm 8 \mathrm{~nm}$. Small particles of the second phases, $10-20 \mathrm{~nm}$ in size, were observed in grain bodies and along grain boundaries (Figure 6). The diffraction con-
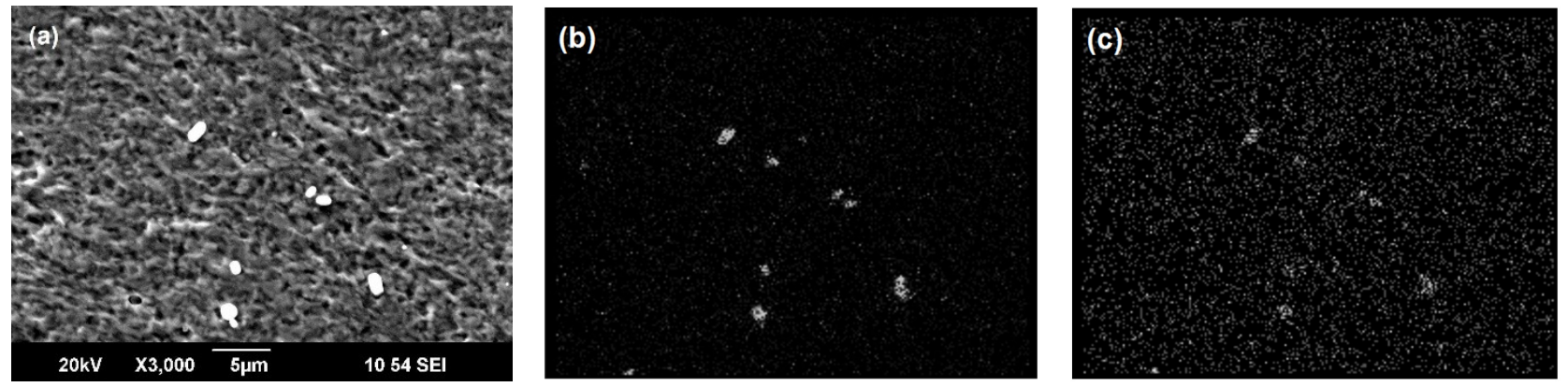

Figure 5: Alloy Cu-0.55Cr-0.2Cd-0.02Zr after eight ECAP cycles + HT at $400^{\circ} \mathrm{C}$ for $1 \mathrm{~h}$ : a-structure (SEM); b-Cr distribution pattern; $\mathrm{c}-\mathrm{Zr}$ distribution pattern. 
trast observed along the boundaries of some grains indicated the process of relaxation of crystallographic planes.

\subsection{Physical and mechanical properties}

As seen from Table 4, the main hardening of the material occurs in the process of deformation. Alloying the dispersion-hardening alloy with cadmium, a strainhardening element, affects not only the strain hardening but also the aging kinetics. Studies on the thermal stability of an alloy of the $\mathrm{Cu}-\mathrm{Cr}$-Cd-Zr system showed that the optimal temperature of the post-deformation heat treatment of the alloy decreased from 450 [14] to $400^{\circ} \mathrm{C}$ (Figure 7).

Wear tests showed a decrease in the track width of the $\mathrm{Cu}-\mathrm{Cr}$-Cd-Zr system alloy after ECAP treatment (Figure 8) relative to the initial coarse-grained state by $10 \%$ and industrial processing of the $\mathrm{Cu}-\mathrm{Cr}-\mathrm{Zr}$ system alloy by $5 \%$. Aging led to decomposition of the supersaturated solid solution of chromium and zirconium and to an increase in the wear resistance by 35 and $12 \%$ compared to commercial $\mathrm{Cu}$ $\mathrm{Cr}-\mathrm{Zr}$ and $\mathrm{Cu}-\mathrm{Cd}$ system alloys, respectively.

Experiments showed that the $\mathrm{Cu}-0.55 \mathrm{Cr}-0.2 \mathrm{Cd}-0.02 \mathrm{Zr}$ alloy, after high-temperature treatment at $1050^{\circ} \mathrm{C}$ for $1 \mathrm{~h}$ followed by cooling in water in contact with an indenter of R6M5, demonstrated the lowest bearing capacity among the studied materials. This may be a limiting point for using the $\mathrm{Cu}-0.55 \mathrm{Cr}-0.2 \mathrm{Cd}-0.02 \mathrm{Zr}$ alloy in friction units after the above heat treatment.

Subsequent analysis of the dependences of adhesive bonds' shear strength on the normal pressure on the contact revealed (Figure 9) that all the tribocouplings had a higher bearing capacity at room temperature. This observation is quite natural because, with temperature growth, the bearing capacity of a tribocoupling should decrease. However, for the $\mathrm{Cu}-\mathrm{Cr}$-Cd-Zr-R6M5 contact pair after eight ECAP passes and subsequent aging at $400^{\circ} \mathrm{C}$ for $1 \mathrm{~h}$, the bearing capacity of the tribological contact in the considered temperature range from 20 to $150^{\circ} \mathrm{C}$ was practically retained. This can be explained by the high thermal stability of the Cu-Cr-Zr system alloys [11-14].

The investigated, non-deformed $\mathrm{Cu}-\mathrm{Cr}-\mathrm{Zr}$ alloy in contact with R6M5, high-speed tool steel, also has high bearing capacity, which is most likely due to the chemical composition of the alloy and the quantitative ratio of alloying elements in the copper matrix.

In addition, the experiments performed on the samples after severe plastic deformation, as well as on the as-

Table 4: Strength properties and electrical conductivity

\begin{tabular}{llll}
\hline & $\begin{array}{l}\text { Microhardness, } \\
\mathrm{MPa}\end{array}$ & $\begin{array}{l}\text { Ultimate tensile strength, } \\
\mathrm{MPa}\end{array}$ & $\begin{array}{l}\text { Electrical conductivity, } \\
\% \text { IACS }\end{array}$ \\
\hline $\mathrm{Cu}-1 \mathrm{Cd}$ industrial processing & $1230 \pm 40$ & $350 \pm 10$ & $78 \pm 2$ \\
$\mathrm{Cu}-0.7 \mathrm{Cr}-0.02 \mathrm{Zr}$ industrial processing & $1825 \pm 40$ & $445 \pm 10$ & $80 \pm 2$ \\
$\mathrm{Cu}-0.55 \mathrm{Cr}-0.2 \mathrm{Cd}-0.02 \mathrm{Zr}$ Casting $+1050^{\circ} \mathrm{C}$ & $820 \pm 40$ & $290 \pm 10$ & $60 \pm 2$ \\
$\mathrm{Cu}-0.55 \mathrm{Cr}-0.2 \mathrm{Cd}-0.02 \mathrm{Zr} 8$ ECAP passes & $1790 \pm 40$ & $550 \pm 10$ & $32 \pm 2$ \\
$\mathrm{Cu}-0.55 \mathrm{Cr}-0.2 \mathrm{Cd}-0.02 \mathrm{Zr} 8$ ECAP passes & $2020 \pm 40$ & $570 \pm 10$ & $67 \pm 2$ \\
$+400^{\circ} \mathrm{C} 1 \mathrm{~h}$ & & & \\
\hline
\end{tabular}

Table 5: Assessment of tribological parameters of the contact on bronze after different treatment

\begin{tabular}{|c|c|c|c|c|c|c|}
\hline Material & $\boldsymbol{\theta},{ }^{\circ} \mathrm{C}$ & $\begin{array}{c}p_{r}, \\
M P a\end{array}$ & $\begin{array}{c}\tau_{n}, \\
M P a\end{array}$ & $\begin{array}{c}\boldsymbol{\tau}_{\boldsymbol{n}} / \\
\boldsymbol{p}_{\boldsymbol{r}}\end{array}$ & $\boldsymbol{\beta}$ & $\begin{array}{c}\tau_{0}, \\
M P a\end{array}$ \\
\hline \multirow{2}{*}{$\mathrm{Cu}-1 \mathrm{Cd}$ (industrial processing) - R6M5 } & 20 & 1203 & 67 & 0.056 & 0.040 & 19 \\
\hline & 150 & 1064 & 86 & 0.081 & 0.081 & 0 \\
\hline \multirow{2}{*}{$\mathrm{Cu}-1 \mathrm{Cr}-0.05 \mathrm{Zr}$ (industrial processing) - R6M5 } & 20 & 1836 & 147 & 0.080 & 0.062 & 34 \\
\hline & 150 & 1283 & 76 & 0.059 & 0.031 & 37 \\
\hline \multirow{2}{*}{ Cu-0.55Cr-0.2Cd-0.02Zr ( $1050^{\circ} \mathrm{C} 1$ hour $)-\mathrm{R} 6 \mathrm{M} 5$} & 20 & 497 & 40 & 0.081 & 0.076 & 3 \\
\hline & 150 & 450 & 46 & 0.101 & 0.065 & 16 \\
\hline \multirow{2}{*}{$\mathrm{Cu}-0.55 \mathrm{Cr}-0.2 \mathrm{Cd}-0.02 \mathrm{Zr}\left(1050^{\circ} \mathrm{C}, 8 \mathrm{ECAP}\right.$ passes $)-\mathrm{R} 6 \mathrm{M} 5$} & 20 & 1989 & 159 & 0.080 & 0.064 & 32 \\
\hline & 150 & 1470 & 171 & 0.117 & 0.088 & 42 \\
\hline $\mathrm{Cu}-0.55 \mathrm{Cr}-0.2 \mathrm{Cd}-0.02 \mathrm{Zr}\left(1050^{\circ} \mathrm{C}, 8 \mathrm{ECAP}\right.$ passes, $400^{\circ} \mathrm{C} 1$ hour $)$ & 20 & 1579 & 201 & 0.127 & 0.096 & 49 \\
\hline - R6M5 & 150 & 1579 & 194 & 0.123 & 0.112 & 17 \\
\hline
\end{tabular}



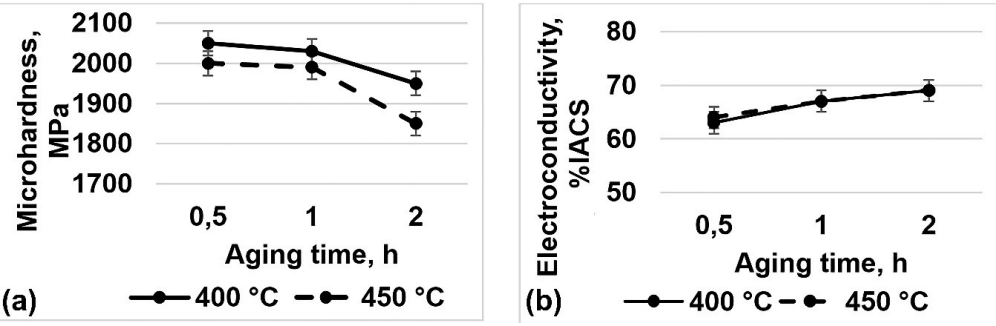

Figure 7: Change in microhardness and electrical conductivity depending on the time and temperature of aging: $a-$ microhardness; $b-$ electrical conductivity.
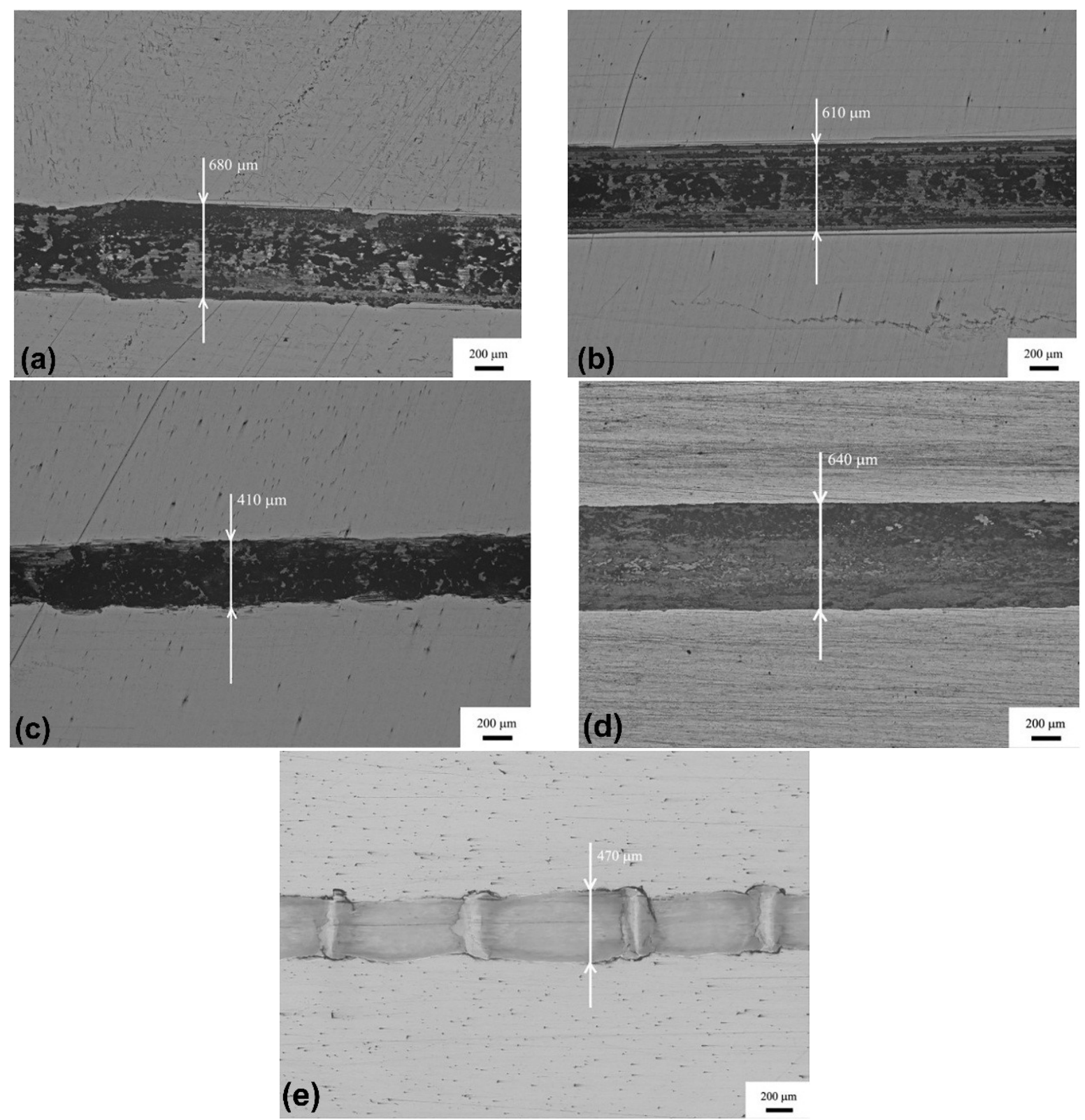

Figure 8: Track width after wear test of copper alloys at a load of $1 \mathrm{~N}$ : $\mathrm{a}-\mathrm{Cu}-0,55 \mathrm{Cr}-0,2 \mathrm{Cd}-0,02 \mathrm{Zr}$ at $1050^{\circ} \mathrm{C}$ for $1 \mathrm{~h} ; \mathrm{b}-\mathrm{Cu}-0,55 \mathrm{Cr}-0,2 \mathrm{Cd}$ $0,02 \mathrm{Zr}$ after eight ECAP cycles; c-Cu-0,55Cr-0,2Cd-0,02Zr ECAP after eight cycles $+400^{\circ} \mathrm{C}$ for $1 \mathrm{~h}$; $\mathrm{d}-\mathrm{Cu}-1 \mathrm{Cr}-0,05 \mathrm{Zr}$ industrial processing; e-Cu-1Cd industrial processing. 


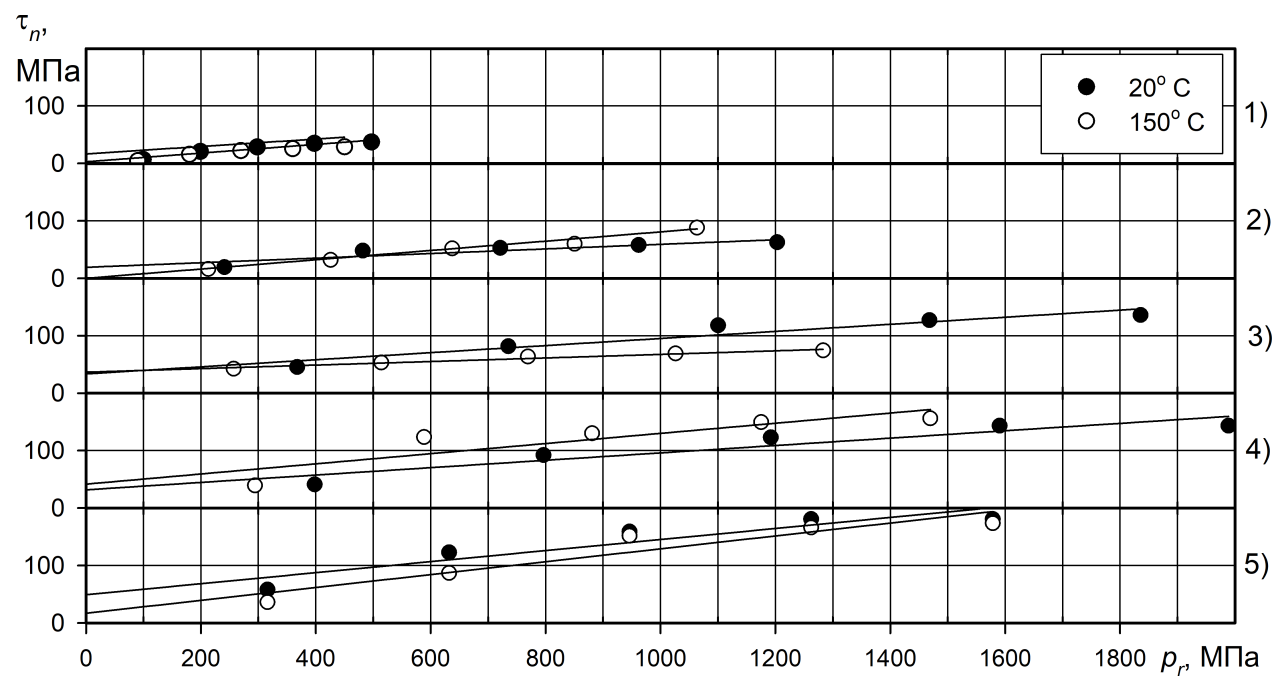

Figure 9: The dependence of the strength of the adhesive bond shear from normal stress on the contact: 1$) \mathrm{Cu}-0,55 \mathrm{Cr}-0,2 \mathrm{Cd}-0,02 \mathrm{Zr}\left(1050^{\circ} \mathrm{C}\right.$, $1 \mathrm{~h})$ - P6M5; 2) Cu-1Cd (industrial processing) - P6M5; 3) Cu-1Cr-0,05Zr (industrial processing) - P6M5; 4) $\mathrm{Cu}-0,55 \mathrm{Cr}-0,2 \mathrm{Cd}-0,02 \mathrm{Zr}\left(1050^{\circ} \mathrm{C}\right.$, eight ECAP cycles) - P6M5; 5) Cu-0,55Cr-0,2Cd-0,02Zr ( $1050^{\circ} \mathrm{C}$, eight ECAP cycles, $400^{\circ} \mathrm{C}$ for $\left.1 \mathrm{~h}\right)-\mathrm{P} 6 \mathrm{M} 5$.

received $\mathrm{Cu}-1 \mathrm{Cr}-0.05 \mathrm{Zr}$ alloy, demonstrated an increase in the shear strength of adhesive bonds with a simultaneous growth in pressure in the contact zone. Moreover, the normal pressure growth was slightly ahead of the increase in the shear strength of adhesive bonds, which led to some decrease in the adhesive component of the friction coefficient. Table 5 presents the results of the evaluation of the contact tribological parameters. Here, $\beta$ is the hardening coefficient of molecular bonds under the action of compressive stresses, and $\tau_{0}$ is the shear strength of adhesive bonds in the absence of normal load.

According to the results of chemical energy dispersive analysis (SEM), cadmium was in the solid solution of the copper matrix both after ECAP and aging. Microstructural analysis showed that, after ECAP, almost no fine particles were observed, which may be associated with a decrease in the diffusion activity of chromium and zirconium in the copper matrix due to distortions introduced by cadmium atoms. At the same time, fine particles are natural stoppers for dislocations and their accumulations, and their absence, in turn, leads to a freer migration of dislocations. The solid solution of cadmium naturally leads to changes in the aging kinetics of the $\mathrm{Cu}-\mathrm{Cr}-\mathrm{Cd}-\mathrm{Zr}$ alloy. When directional stresses do not act in the material, $\mathrm{Cd}$ in a solid solution, like Sn, can increase the rate of formation of small nuclei, as well as the coalescence of large particles [15].

Cadmium, in the form of a solid solution, plays an important role in improving wear-resistant properties, since, among solid-solution elements, it, best of all, contributes to an increase in the resistance of a copper matrix to abrasion [16]. The results of tribological tests of the sample of the alloy of the Cu-Cr-Cd-Zr system after ECAP and aging indicate a less plastic behavior of the sample in the considered frictional contact. At the same time, in the course of a preliminary assessment of the amount of wear and determination of the shear strength of adhesive bonds, it was experimentally found that the alloy of the $\mathrm{Cu}-\mathrm{Cr}-\mathrm{Cd}-\mathrm{Zr}$ system after ECAP, during wear, can withstand higher loads at $150^{\circ} \mathrm{C}$ than industrial alloys of the $\mathrm{Cu}-\mathrm{Cd}$ and $\mathrm{Cu}-\mathrm{Cr}$ - $\mathrm{Zr}$ systems, as evidenced by preservation of the bearing capacity of the tribological contact of the alloy $\mathrm{Cu}-\mathrm{Cr}-\mathrm{Cd}-\mathrm{Zr}$ system at 20 and $150^{\circ} \mathrm{C}$.

\section{Conclusions}

1. Microalloying with cadmium $0.2 \%$ wt. $\mathrm{Cu}-\mathrm{Cr}-\mathrm{Zr}$ alloy and SPD by ECAP with subsequent aging at $400^{\circ} \mathrm{C}$ leads to the formation of an UFG structure with an average grain size of $215 \pm 8 \mathrm{~nm}$ and an increase in the ultimate strength to $570 \pm 10 \mathrm{MPa}$, which is higher than in relation to modern industrial samples of cadmium and chromium aged zirconium bronze by 36 and $28 \%$, respectively.

2. The alloy of the $\mathrm{Cu}-\mathrm{Cr}-\mathrm{Cd}-\mathrm{Zr}$ system has a sufficiently high thermal stability at $400^{\circ} \mathrm{C}$, which is twice the value of the thermal stability of cadmium bronzes.

3. The alloy of the $\mathrm{Cu}-\mathrm{Cr}-\mathrm{Cd}-\mathrm{Zr}$ system demonstrates higher wear resistance, which increases by 12 and $35 \%$ relative to the industrial $\mathrm{Cu}-\mathrm{Cd}$ and $\mathrm{Cu}-\mathrm{Cr}-\mathrm{Zr}$ systems, respectively. 
4. It was found that the bearing capacity of the tribological contact of the $\mathrm{Cu}-\mathrm{Cr}-\mathrm{Cd}-\mathrm{Zr}$ pair after ECAP and aging and ShKh15 under dry friction conditions from 20 to $150^{\circ} \mathrm{C}$ of the alloy remains at $1579 \mathrm{MPa}$, which is higher than the bearing capacity at $150^{\circ} \mathrm{C}$ of industrial alloys of the $\mathrm{Cu}-\mathrm{Cd}$ and $\mathrm{Cu}-\mathrm{Cr}-\mathrm{Zr}$ systems.

5. Severe plastic deformation by the ECAP method of the dispersion-hardening alloy of the $\mathrm{Cu}-\mathrm{Cr}-\mathrm{Cd}-\mathrm{Zr}$ system leads to an increase in the shear strength of adhesive bonds with a simultaneous increase in pressure in the contact zone.

6. Electrical conductivity of the $\mathrm{Cu}-\mathrm{Cr}-\mathrm{Cd}-\mathrm{Zr}$ system alloy after deformation by the ECAP method and subsequent aging at $400^{\circ} \mathrm{C}$ for $1 \mathrm{~h}$ is $67 \%$, which meets the requirements for high-strength copper alloys for electrical purposes.

7. The developed alloy, $\mathrm{Cu}-0.55 \mathrm{Cr}-0.2 \mathrm{Cd}-0.02 \mathrm{Zr}$, has advantages and prospects for industrial use as a material for electrical purposes for tips and collector plates.

Acknowledgement: This work was supported by the Ministry of Education of the Russian Federation, project 08382020-0006 «Fundamental study of new principles for the creation of promising electromechanical energy converters with characteristics above the world level, with increased efficiency and minimum specific indicators, using new highly efficient electrotechnical materials»

The authors are grateful to the Center of Collective Use "Nanotech" at USATU (Ufa, Russia) for providing the equipment for tribological studies.

\section{References}

[1] Purcek, G., H. Yanar, O. Saray, I. Karaman, and H. J. Maier. Effect of precipitation on mechanical and wear properties of ultrafinegrained Cu-Cr-Zr alloy. Wear, Vol. 311, No. 1-2, 2014, pp. 149158.

[2] Semenov, V. I., L.Sh. Shuster, S.-J. Huang, and P.-Ch. Lin. Commercially pure copper and low-alloyed chrome bronze in tribological contact with graphitiferous materials. Machines. Technologies. Materials. Vol. 9, 2014, pp. 36-39.

[3] Semenov, V. I., S.J. Huang, V.G. Shibakov, L.Sh. Shuster, S.N. Faizova, and P.-Ch. Lin. Tribological properties of commercially pure copper with different microstructures, in contact with a graphitic material. Journal of Friction and Wear. Vol. 36, 2015, pp. 118-122.
[4] Purcek, G., H. Yanar, M. Demirtas, D. V. Shangina, N. R. Bochvar, and S. V. Dobatkin. Microstructural, mechanical and tribological properties of ultrafine-grained $\mathrm{Cu}-\mathrm{Cr}-\mathrm{Zr}$ alloy processed by high pressure torsion. Journal of Alloys and Compounds, Vol. 816, 2020, p. 152675.

[5] Purcek, G., H. Yanar, D. V. Shangina, M. Demirtas, N. R. Bochvar, and S. V. Dobatkin. Influence of high pressure torsion-induced grain refinement and subsequent aging on tribological properties of Cu-Cr-Zr alloy. Journal of Alloys and Compounds, Vol. 742, 2018, pp. 325-333.

[6] Zhilyaev, A. P., A. Morozova, J. M. Cabrera, R. Kaibyshev, and T. $\mathrm{G}$. Langdon. Wear resistance and electroconductivity in a $\mathrm{Cu}-0.3$ $\mathrm{Cr}-0.5 \mathrm{Zr}$ alloy processed by ECAP. Journal of Materials Science, Vol. 52, No. 1, 2016, pp. 305-313.

[7] Liu, Y., Z. Li, Y. Jiang, Y. Zhang, Z. Zhou, and Q. Lei. The microstructure evolution and properties of a $\mathrm{Cu}-\mathrm{Cr}-\mathrm{Ag}$ alloy during thermalmechanical treatment. Journal of Materials Research, Vol. 32, No. 7, 2017, pp. 1324-1332.

[8] Liang, D., X. Mi, L. Peng, H. Xie, G. Huang, and Z. Yang. Relationship between Microstructure and Properties of $\mathrm{Cu}-\mathrm{Cr}-\mathrm{Ag}$ Alloy. Materials (Basel), Vol. 13, No. 3, 2020, id. 732.

[9] Shuster, L. Sh. Adhesive interaction of solid metal bodies. Gilem, Ufa, 1999 (In Russian).

[10] Vinogradov, A., T. Ishida, K. Kitagawa, and V. I. Kopylov. Effect of strain path on structure and mechanical behavior of ultra-fine grain $\mathrm{Cu}$ ? $\mathrm{Cr}$ alloy produced by equal-channel angular pressing. Acta Materialia, Vol. 53, No. 8, 2005, pp. 2181-2192.

[11] Vinogradov, A., V. Patlan, Y. Suzuki, K. Kitagawa, and V. I. Kopylov. Structure and properties of ultra-fine grain $\mathrm{Cu}-\mathrm{Cr}-\mathrm{Zr}$ alloy produced by equal-channel angular pressing. Acta Materialia, Vol. 50, No. 7, 2002, pp. 1639-1651.

[12] Morozova, A., R. Mishnev, A. Belyakov, and R. Kaibyshev. Microstructure and Properties of Fine Grained Cu-Cr-Zr Alloys after Termo-Mechanical Treatments. Reviews on Advanced Materials Science, Vol. 54, No. 1, 2018, pp. 56-92.

[13] Faizov, I., G. I. Raab, and D. Aksenov. Contributions of Various Strengthening Mechanisms to the Flow Onset Stress in the ECAPProcessed Cu-Cr-Zr Alloy. Key Engineering Materials, Vol. 743, 2017, pp. 197-202.

[14] Aksenov, D. A., R. Asfandiyarov, G. I. Raab, G. B. Isyandavletova. Features of the physico-mechanical behavior of UFG low-alloyed bronze $\mathrm{Cu}-1 \mathrm{Cr}-0.08 \mathrm{Zr}$ produced by severe plastic deformation. Proceedings of the 4 th International Conference Recent Trends in Structural Materials, November 9-11 2016, Pilsen, Czech Republic, IOP Conference Series: Materials Science and Engineering, Vol. 179, 2017, id. 012001.

[15] Luo, Z., F. Luo, W. Xie, H. Chen, H. Wang, and B. Yang. The Effect of Precipitation Characteristics on Hardening Behavior in $\mathrm{Cu}-\mathrm{Cr}-\mathrm{Sn}$ Alloy with Sn Variation. Powder Metallurgy and Metal Ceramics, Vol. 58, No. 11-12, 2020, pp. 657-666.

[16] Mysik, R. K., and Ju. N. Loginov. Problems of casting and processing cadmium bronze. Ekaterinbirg, UGTY, 2006. (In Russian) 